\title{
Cassava/Maize Intercrop Performance and Soil Nutrient Changes with Fertilizers
}

\author{
O.T. Ayoola (Corresponding author) \\ South West Farming System Research and Extension Programme \\ Institute of Agricultural Research and Training, Obafemi Awolowo University \\ P.M.B 5029, Moor Plantation, Ibadan, Nigeria \\ E-mail: otayoola@yahoo.com \\ E.A. Makinde \\ Department of Horticulture, University of Agriculture \\ P.M.B 2204, Abeokuta, Nigeria
}

Received: August 9, 2011

Accepted: August 29, 2011 Published: December 1, 2011

doi:10.5539/jas.v3n4p136

URL: http://dx.doi.org/10.5539/jas.v3n4p136

\begin{abstract}
Field trials were conducted in the forest vegetation (Ibadan) and the derived savannah (Ilora) zones of south west Nigeria to assess the yield performance of cassava/maize intercrop and soil nutrient changes with sole and some combined ratios of organic-based fertilizer (OBF) and inorganic fertilizer. Sole OBF was assessed at 2.5; 5.0 and $10.0 \mathrm{t} \mathrm{ha}^{-1}$ while $400 \mathrm{~kg} \mathrm{ha}^{-1} \mathrm{NPK} 15-15-15$ served as the sole inorganic fertilizer treatment. The combined treatments were: $2.5 \mathrm{t} \mathrm{ha}^{-1} \mathrm{OBF}+100 \mathrm{~kg} \mathrm{ha}^{-1} \mathrm{NPK} 15-15-15$ and $5 \mathrm{t} \mathrm{ha}^{-1} \mathrm{OBF}+100 \mathrm{~kg} \mathrm{ha}^{-1} \mathrm{NPK} 15-15-15$. An unfertilized treatment served as the control treatment. Maize grain yield was highest with application of $5 \mathrm{t}^{-1}$ $\mathrm{OBF}+100 \mathrm{~kg} \mathrm{ha}^{-1} \mathrm{NPK}$. It gave a mean yield of $2.45 \mathrm{t} \mathrm{ha}^{-1}$ at Ibadan and $2.49 \mathrm{t} \mathrm{ha}^{-1}$ at Ilora. Cassava root yield was however highest with $10 \mathrm{t} \mathrm{ha}^{-1} \mathrm{OBF}$. It gave a mean yield of $14.55 \mathrm{t} \mathrm{ha}^{-1}$ at Ibadan and $12.52 \mathrm{t} \mathrm{ha}^{-1}$ at $\mathrm{Ilora}_{\text {. }}$ Soil N, P, K and Organic C was most increased with $10 \mathrm{t} \mathrm{ha}^{-1} \mathrm{OBF}$ and $5 \mathrm{t} \mathrm{ha}^{-1} \mathrm{OBF}+\mathrm{NPK}$. Crop yields and soil nutrient status decreased with no fertilizer application. Cassava -maize intercrop gives optimum yields and highest soil N, P, K increase with $10 \mathrm{t} \mathrm{ha}^{-1} \mathrm{OBF}$.
\end{abstract}

Keywords: Organic--based fertilizer, NPK, Cassava, Maize

\section{Introduction}

Intercropping produces a stable and sustainable agro-ecosystem in the humid tropics. Farmers in the south western part of Nigeria practice intercropping with a wide range of crops. Cassava - based cropping system is particularly favoured because it is a major staple consumed by many households. Cassava is suited to intercropping because of its initial slow growth rate with its field maturity period of 12 to 18 months and the establishment at a wide spacing of $1 \mathrm{~m}$. It is usually intercropped with short duration crops like maize. Cassava / maize intercrop is a popular intercrop combination in many areas of the southern part of Nigeria. Various intercropping systems practiced in Africa and Asia involving cassava have been reported (Ofori and Stern, 1987; Amanullah et al., 2006). Competition however exists for available resources among crops planted in mixtures which could lead to yield depression (Ikeorgu, 1984; Ambe et al., 1988). There is therefore need for adequate replenishment of soil nutrients when crops are planted in mixtures. Inorganic fertilizer use has been the standard nutrient supply means for a long time but its intensive use has been associated with reduced crop yield due to soil acidity and nutrient imbalance (Kang and Juo, 1980; Agboola and Omueti, 1982, Adediran et al., 2004). The huge quantities required to satisfy the nutritional needs of crops; the burden of transportation as well as handling cost have not allowed farmers to utilize the full benefits of organic materials. Several research workers have supported the use of organic materials mixed with mineral fertilizers or complementary use of both for achieving high and sustainable high crop yields (Adediran et al., 2004; Abou El-Magd et al., 2006). This study was therefore conducted to assess the yields of cassava/maize intercropped with different rates of organic-based 
fertilizer prepared by researchers in the Institute of Agricultural Research and Training, Ibadan as well as its combination with a quarter of the recommended rates of inorganic fertilizer and soil nutrient changes after cropping for two years.

\section{Materials and Methods}

Field trials were conducted at the Institute of Agricultural Research and Training (IAR\&T) at Ibadan (latitude $7^{0}$ $22.5^{\prime} \mathrm{N}$; longitude $3^{0} 55^{\prime} \mathrm{E}$ ) in the rain forest vegetation zone and at Ilora (latitude $7^{0} 45^{\prime} \mathrm{N}$; longitude $3^{0} 55^{\prime} \mathrm{E}$ ) in the derived savannah agro ecology both in south west Nigeria. It was conducted during the 2006 and 2007 cropping seasons. Total annual rainfall for Ibadan was $1528 \mathrm{~mm}$ and $1224 \mathrm{~mm}$ in 2006 and 2007, respectively. It was $1111 \mathrm{~mm}$ in 2006 and $1363 \mathrm{~mm}$ in 2007 at Ilora. Samples of top soil $(0-20 \mathrm{~cm})$ were taken from the trial sites prior planting while samples were taken per plot after cropping for two years. The samples were air dried, crushed and passed through a $2 \mathrm{~mm}$ sieve; afterwards, routine analyses were carried out following IITA procedures (1979). Soil $\mathrm{pH}$ was determined in distilled water at 1:1 soil to water ratio. The Total $\mathrm{N}$ was determined by the micro-Kjeldahl method. Percentage Organic Matter was derived by multiplying \% organic carbon by Broadbent's factor of 1.72 (Broadbent, 1953). Available P was determined by the Bray's P1 test, using $0.03 \mathrm{NH}_{4} \mathrm{~F}$ in $0.02 \mathrm{~N} \mathrm{HCl}$ as extractant and measuring the extracted $\mathrm{P}$ colorimerically by the molybdenum blue method. Exchangeable bases were determined by extraction with neutral normal $\mathrm{NH}_{4} \mathrm{OAC}$ at soil: solution ratio, 1:10.The results of the pre-cropping analysis are presented in Table 1.The experiments were laid out in a randomized complete block design with three replications. There were seven treatments which consisted of (i) $2.5 \mathrm{t} \mathrm{ha}^{-1}$ Organic -based fertilizer (OBF) (ii) $5 \mathrm{t} \mathrm{ha}^{-1} \mathrm{OBF}$ (iii) $10 \mathrm{tha}^{-1} \mathrm{OBF}$ (iv) $2.5 \mathrm{t} \mathrm{ha}^{-1} \mathrm{OBF}+100 \mathrm{~kg} \mathrm{ha}^{-1}$ NPK 15-15-15 (v) $5 \mathrm{t} \mathrm{ha}^{-1} \mathrm{OBF}+100 \mathrm{~kg} \mathrm{ha}^{-1}$ NPK 15-15-15 (vi) $400 \mathrm{~kg} \mathrm{ha}^{-1}$ NPK 15-15-15 and (vii) control (no fertilizer). The organic - based fertilizer was prepared from shredded maize straw, cobs and sheaths composted with poultry manure and mixed with $25 \mathrm{~kg} \mathrm{ha}^{-1} \mathrm{NPK} 20-10-10$. The organic - based fertilizer had a $\mathrm{pH}$ of 7.3 with $1.92 \%, 0.10 \%, 1.07 \%, 6.42 \%$ and $15.6 \%$ of total $\mathrm{N}$, available $\mathrm{P}$, exchangeable $\mathrm{K}$, exchangeable $\mathrm{Ca}$ and Organic Carbon contents, respectively. It was worked into the soil before planting while the inorganic fertilizer was applied by side dressing about $5 \mathrm{~cm}$ beside maize plant 3 weeks after planting. Cassava variety: TMS 30572 (IITA, Nigeria1994) was planted with maize variety: TZPBR-W (IITA, Nigeria1994). Planting was done on the flat after ploughing and harrowing. Cassava was planted at $90 \mathrm{~cm}$ x $90 \mathrm{~cm}$ spacing while maize was planted at 90 $\mathrm{cm} \times 45 \mathrm{~cm}$ ( 2 plants / stand). Plot size was $5 \mathrm{~m}$ x $4 \mathrm{~m}$. The plots were hand weeded twice before maize harvesting ( 3 and 6 weeks after planting) and at 7 days after maize harvesting. Maize was harvested at 14 weeks after planting and dried to $14 \%$ moisture content to obtain the dry grain weight. Cassava was harvested 12 months after planting for the root yield record. Data analysis was done using analysis of variance (ANOVA) procedure and means separated by New Duncan's Multiple Range Tests at 0.05 level of probability when the Fratio was significant.

\section{Results}

Maize grain yields followed the same pattern in both cropping years at both locations. In Ibadan, highest maize grain yields of $2.42 \mathrm{t} \mathrm{ha}^{-1}$ in 2006 and $2.48 \mathrm{t} \mathrm{ha}^{-1}$ in 2007 were got from application of $5 \mathrm{t} \mathrm{ha}^{-1} \mathrm{OBF}+\mathrm{NPK}$. It also gave the highest yields of $2.46 \mathrm{t} \mathrm{ha}^{-1}$ in 2006 and $2.52 \mathrm{t} \mathrm{ha}^{-1}$ in 2007 respectively, at Ilora. These yields were not significantly higher than obtained from $10 \mathrm{t} \mathrm{ha}^{-1} \mathrm{OBF}$ and from sole NPK in both years at both locations (Table 2). The unfertilized plants gave significantly lower grain yields of 0.98 and $0.88 \mathrm{t} \mathrm{ha}^{-1}$, respectively in 2006 and 2007 at Ibadan while it gave 0.97 and $0.82 \mathrm{t} \mathrm{ha}^{-1}$ in 2006 and 2007, respectively at Ilora. Maize grain yields were generally higher for the various fertilizer treatments in Ilora than Ibadan. Highest cassava root yields of 14.3 and $14.8 \mathrm{tha}^{-1}$ in 2006 and 2007, respectively at Ibadan with 12.3 and $12.7 \mathrm{tha}^{-1}$ at Ilora were from application of 10 $\mathrm{t} \mathrm{ha}^{-1} \mathrm{OBF}$. Yields from $5 \mathrm{tha}^{-1} \mathrm{OBF}$ were not significantly higher than from application of $10 \mathrm{tha}^{-1} \mathrm{OBF}+\mathrm{NPK}$ for both locations but were significantly higher than from sole NPK fertilizer application, only in Ibadan. In Ilora however, the yields were similar. The lowest cassava root yields were from the control (no fertilizer). Cassava yields were generally lower in Ilora than Ibadan. Soil Nitrogen was reduced with cropping, where no fertilizer was applied. It reduced from an initial $1.20 \mathrm{~g} \mathrm{~kg}^{-1}$ to $0.90 \mathrm{~g} \mathrm{~kg}^{-1}$ in Ibadan and from $0.89 \mathrm{~g} \mathrm{~kg}^{-1}$ to $0.64 \mathrm{~g} \mathrm{~kg}^{-1} \mathrm{~g} \mathrm{in}^{-1}$ Ilora. Total $\mathrm{N}$ content increased by $22 \%$ where $5 \mathrm{t} \mathrm{ha}^{-1} \mathrm{OBF}+\mathrm{NPK}$ was applied and by $20 \%$ where $10 \mathrm{t} \mathrm{ha}^{-1}$ OBF was applied but increased by $3 \%$ where NPK fertilizer was applied in Ibadan. The same trend was also observed in Ilora. Highest P increase was from application of $5 \mathrm{t} \mathrm{ha}^{-1} \mathrm{OBF}+\mathrm{NPK}$ in Ibadan but the highest value was obtained with $10 \mathrm{t} \mathrm{ha}^{-1} \mathrm{OBF}$ in Ilora. Available P content was slightly reduced with NPK fertilization in both locations, with the lowest value from the control, unfertilized plants. Exchangeable $\mathrm{K}$ increased by $21 \%$ with application of $10 \mathrm{t} \mathrm{ha}^{-1} \mathrm{OBF}$ in Ibadan and by $25 \%$ at Ilora. It was however reduced by $36 \%$ and $37.5 \%$ in the control, unfertilized plants and by $14 \%$ and $16.7 \%$ with NPK fertilization in Ibadan and Ilora respectively (Table 4). Exchangeable $\mathrm{K}$ contents increased from between 4 and $8 \%$ with other OBF treatments with or without addition of NPK in both locations except with $2.5 \mathrm{t} \mathrm{ha}^{-1}$ OBF where it decreased by $14 \%$ and $12.5 \%$ in Ibadan 
and Ilora respectively. Organic $\mathrm{C}$ increased from $10.20 \mathrm{~g} \mathrm{~kg}^{-1}$ to $12.85 \mathrm{~g} \mathrm{~kg}^{-1}$ in Ibadan and from $7.10 \mathrm{~g} \mathrm{~kg}^{-1}$ to $8.55 \mathrm{~g} \mathrm{~kg}^{-1}$ in Ilora. It increased by a range of $3 \%$ to $9 \%$ for all other OBF treatments with or without NPK addition at both locations except with $2.5 \mathrm{t} \mathrm{ha}^{-1} \mathrm{OBF}$ treatments where there were slight decreases. Organic $\mathrm{C}$ decreased by $19 \%$ with NPK fertilizer alone and by $21 \%$ without fertilization in Ibadan. In Ilora, it reduced from an initial value of $7.10 \mathrm{~g} \mathrm{~kg}^{-1}$ to $6.13 \mathrm{~g} \mathrm{~kg}^{-1}$ with NPK fertilizer and $5.66 \mathrm{~g} \mathrm{~kg}^{-1}$ with no fertilizer.

\section{Discussion}

Maize intercropped with cassava was able to exploit the micro environment early in the growing season from the results of this trial. Maize yields were highest with complementary inorganic fertilizer (NPK) and the Organic-based fertilizer (OBF). Nutrients released early from inorganic source were utilized by maize, which is an aggressive feeder to give better yields than OBF alone. This is an indication that the nutrient use efficiency increased with addition of NPK to organic fertilizer. Similar observations have been earlier made (Makinde and Agboola, 2002; Adeniyan and Ojeniyi, 2005; Ayoola and Makinde, 2009). Early release of nutrients from NPK fertilizer also favoured maize grain yield in both years at both locations. Maize grain yields with application of $10 \mathrm{t} \mathrm{ha}^{-1}$ OBF was comparable to yields with OBF + NPK and NPK alone probably because of the high rate of application that is likely to have released enough nutrients to compare with either complemented application or sole inorganic application. Nutrient release from organic sources applied at low rates has been found to be usually low for a crop like maize. It has earlier been observed that organic wastes/fertilizers could hardly be depended upon as the sole source of nutrientS for corn (Chung et al., 2000). The observed significantly lower maize yields with 2.5 and $5.0 \mathrm{tha}^{-1} \mathrm{OBF}$ relative to complemented applications is an indication of the need for further fortification of the OBF. Similar observation has been made by Adediran et al. (2004). Fertilization generally increased maize yields due to nutrient release. The observed similar cassava root yields with applications of $10 \mathrm{tha}^{-1} \mathrm{OBF}$ and $5 \mathrm{tha}^{-1} \mathrm{OBF}+\mathrm{NPK}$ is an indication that cassava was able to utilize nutrients applied in the early season throughout its growing period. It further showed the ability of OBF to release nutrients gradually to crops through the growing season (Patel and Meisheri, 1997; Adediran et al., 1999 ;). Application of NPK alone and $2.5 \mathrm{tha}^{-1}$ OBF showed the least residual effect on cassava root yield. Generally, there were improvements in the soil nutrients status where OBF was applied at $5 \mathrm{tha}^{-1}$ and with the two $\mathrm{OBF}+\mathrm{NPK}$ treatments due to release of nutrients. Soil N, P, K and Organic C were increased higher with addition of $10 \mathrm{tha}^{-1} \mathrm{OBF}$ and $5 \mathrm{tha}^{-1} \mathrm{OBF}+\mathrm{NPK}$ than with application of $5 \mathrm{t} \mathrm{ha}^{-1} \mathrm{OBF}$ due to the high rate of application and early release, respectively. Soil N, K and organic C decreased with application of NPK alone due to early release of nutrients for utilization by maize, leading to depletion of the inherent status by the longer maturing cassava. Application of $2.5 \mathrm{tha}^{-1} \mathrm{OBF}$ could not adequately compensate for nutrients uptake by crops and possible loss by leaching and erosion. It has been reported that cassava extracts large quantity of $\mathrm{K}$ from the soil and N, P and K accumulate in its roots (Howeler, 1981; Howeler and Cadavid, 1983). Soil N, P, K and organic $\mathrm{C}$ decreased with no fertilizer application which corroborates earlier observations that tropical soils naturally show nutrient deficiency before cultivation or after short periods of crop growing (Makinde and Agboola, 2002; Ayoola, 2006).

This study has shown that application of organic-based fertilizer (OBF) at $5 \mathrm{t} \mathrm{ha}^{-1}$ complemented with $100 \mathrm{~kg}$ $\mathrm{ha}^{-1} \mathrm{NPK}$ and application of $10 \mathrm{tha}^{-1} \mathrm{OBF}$ gave maize grain and cassava root yields comparable to yields with $400 \mathrm{~kg} \mathrm{ha}^{-1}$ NPK and significantly increased soil nutrients after cropping for two years.

\section{References}

Abou El- Magd M.A., M. El Bassiony \& Z. F. Fawzy. (2006). Effect of organic manure with or without chemical fertilizers on growth, yield and quality of some varieties of Broccoli plants. J. Appl. Sci. Res., 2 (10): 791-798. http://www.aensionline.com/jasr/jasr/2006/791-798.pdf

Adediran J.A. L.B. Taiwo, M.O. Akande, R.A.Sobulo \& O.J. Idowu. (2004). Application of organic and inorganic fertilizer for sustainable maize and cowpea yields in Nigeria. J. Plant Nutrition, 27(7):1163-1181. http://dx.doi.org/10.1081/PLN-120038542

Adediran J.A., M.O. Akande \& G.O. Adeoye. (1999). Comparative effectiveness of organic manures and complementary use of inorganic fertilizers on growth and yield of maize. African Soils, 29: 41-57.

Adeniyan O.N. \& S.O. Ojeniyi. (2005). Effect of poultry manure, NPK 15-15-15 and combination of their reduced levels on maize growth and soil chemical properties. Nig. J. of Soil Sci., 15:34-41.

Agboola A. A. \& J. A. Omueti. (1982). Soil fertility problem and its management in tropical Africa. Paper presented at the International Institute of Tropical Agriculture, Ibadan, Nigeria. 25pp.

Amanullah M.M., K. Vaiyapuri, A. Alagesan, E. Samasundaram, K. Sathyamoorth \& S. Pazhanivelan. (2006). Effect of intercropping and organic manures on the yield and biological efficiency of cassava intercropping 
system (Manihot esculenta Crantz.). Res. J. Agric \& Biol. Sci., 2 (5): 201-208. http://www.aensionline.com/rjabs/rjabs/2006/201-208.pdf

Ambe T. J., S.N. Lyonga, A.A. Agboola \& S.K. Hahn. (1988). The performance of Cassava with other staple in intercrops in Cameroon. In: Proceedings of $1^{\text {st }}$ Annual Meeting of Cassava-based Cropping System Research Group, IITA, Ibadan, Nigeria. pp 91-97.

Ayoola O.T. \& E.A. Makinde. (2009). Maize growth, yield and soil nutrient changes with N-enriched organic fertilizers. African J. Food, Agric. Nutr. Devt., 9:580-592. http://www.ajfand.net/Volume9/No1/Makinde6085.pdf

Broadbent, F.E. (1953). The soil organic fraction. Advances in Agronomy, 5: 153-183. http://dx.doi.org/10.1016/S0065-2113(08)60229-1

Chung R.S, C.H. Wang, C.W. Wang \& Y.P. Wang. (2000). Influence of organic matter and inorganic fertilizer on the growth and Nitrogen accumulation of Corn plants. $J$.Plant Nutrition, 23 (3):297-311. http://dx.doi.org/10.1080/01904160009382017

Howeler R.H. (1981). Mineral and fertilization of cassava. CIAT, Cali, Colombia. 52pp.

Howeler R.H. \& L.F. Cadavid. (1983). Accumulation and distribution of dry matter and nutrients during a 12 month growth cycle of cassava. Field Crops Res., 7: 123-139. http://dx.doi.org/10.1016/0378-4290 (83)90017-5

IITA. (International Institute of Tropical Agriculture) (1979). Selected methods for soil and plant analysis; IITA, Ibadan, Nigeria. Manual series No 1, 70pp.

Ikeorgu J.E.G. (1984). Some micro-environmental changes under cassava (Manihot esculenta Crantz) -maize (Zea mays L) intercrops grown with okra (Abelmoschus esculentus L) and 'egusi' melon (Colocynthis vulgaris L). Ph. D thesis, University of Ibadan, Nigeria. 259pp.

Kang B.T. \& A.S.R. Juo. (1980). Management of low activity clay soils in tropical Africa for food crop production. In: Terry E. R., K. A. Oduro and F. Caveness (Eds) Tropical Root crops: Research strategies for the 1980s. Ottawa, Ontario, IDRC pp129-133.

Makinde E.A \& A.A. Agboola. (2002). Soil nutrient changes with fertilizer type in a cassava-based cropping system. J. Plant Nutr., 25 (10): 2303-2313. http://dx.doi.org/10.1081/PLN-120014077

Ofori F. \& W.R.Stern. (1985). Cereal - Legume intercropping systems. Adv. Agron., San Diego. 41:41 -89. dx.doi.org/doi:10.1080/01904160801894996

Patel R.H \& T.G. Meisheri. (1997). Effect of farmyard manure, nitrogen and source of fertilizer on growth, yield attributes and yields of Indian mustard (Brassica juncea). Indian J. Agric. Sci., 67(6): 237-240. [Online] Available: www.tandfonline.com/doi/abs/10.1081/PLN-120038542

Table 1. Pre cropping soil characteristics of the soils in Ibadan and Ilora

\begin{tabular}{|c|c|c|c|c|}
\hline \multicolumn{3}{|l|}{ Soil properties } & \multicolumn{2}{|c|}{ Values } \\
\hline & & & Ibadan & Ilora \\
\hline $\mathrm{pH}$ & & & 6.00 & 6.40 \\
\hline Total $\mathrm{N}\left(\mathrm{g} \mathrm{kg}^{-1}\right)$ & & & 1.20 & 0.89 \\
\hline Available $\mathrm{P}\left(\mathrm{mg} \mathrm{kg}^{-1}\right)$ & & & 1.60 & 3.60 \\
\hline Exchangeable $\mathrm{K}\left(\mathrm{c} \mathrm{mol} \mathrm{kg}{ }^{-1}\right)$ & & & 0.28 & 0.24 \\
\hline , & $\mathrm{Ca}$ & , & 3.50 & 1.80 \\
\hline , & $\mathrm{Mg}$ & , & 0.18 & 1.13 \\
\hline , & $\mathrm{Na}$ & , & 0.78 & 0.40 \\
\hline Acidity $\mathrm{H}$ & , & & 0.08 & 0.10 \\
\hline $\mathrm{CEC}$ & & , & 4.82 & 3.67 \\
\hline Organic $\mathrm{C} \quad\left(\mathrm{mg} \mathrm{kg}^{-1}\right)$ & & & 10.20 & 7.10 \\
\hline Sand $\quad\left(\mathrm{g} \mathrm{kg}^{-1}\right)$ & & & 850.00 & 880.00 \\
\hline Clay & & & 100.00 & 80.00 \\
\hline Silt $\quad$, & & & 50.00 & 40.00 \\
\hline Textural class & & & Sandy loam & Sandy loam \\
\hline
\end{tabular}


Table 2. Maize grain yield $\left(\mathrm{t} \mathrm{ha}{ }^{-1}\right)$ as affected by different Organic - Based Fertilizer (OBF) rates and combination with NPK in Ibadan and Ilora

\begin{tabular}{lcccc}
\hline & \multicolumn{2}{c}{ Ibadan } & \multicolumn{2}{c}{ Ilora } \\
\hline Treatments & 2006 & 2007 & 2006 & 2007 \\
$2.5 \mathrm{t} \mathrm{ha}^{-1} \mathrm{OBF}$ & $1.64 \mathrm{c}$ & $1.73 \mathrm{c}$ & $1.62 \mathrm{~b}$ & $1.69 \mathrm{~b}$ \\
$5.0 \mathrm{t} \mathrm{ha}^{-1} \mathrm{OBF}$ & $2.07 \mathrm{~b}$ & $2.14 \mathrm{~b}$ & $2.26 \mathrm{a}$ & $2.23 \mathrm{a}$ \\
$10.0 \mathrm{t} \mathrm{ha}^{-1} \mathrm{OBF}$ & $2.20 \mathrm{ab}$ & $2.29 \mathrm{ab}$ & $2.32 \mathrm{a}$ & $2.36 \mathrm{a}$ \\
$2.5 \mathrm{t} \mathrm{ha}^{-1} \mathrm{OBF}+100 \mathrm{~kg} \mathrm{ha}^{-1} \mathrm{NPK}$ & $2.10 \mathrm{~b}$ & $2.25 \mathrm{ab}$ & $2.30 \mathrm{a}$ & $2.25 \mathrm{a}$ \\
$5.0 \mathrm{t} \mathrm{ha}^{-1} \mathrm{OBF}+100 \mathrm{~kg} \mathrm{ha}^{-1} \mathrm{NPK}$ & $2.42 \mathrm{a}$ & $2.48 \mathrm{a}$ & $2.46 \mathrm{a}$ & $2.52 \mathrm{a}$ \\
$400 \mathrm{~kg} \mathrm{ha}^{-1} \mathrm{NPK}$ & $2.38 \mathrm{a}$ & $2.35 \mathrm{ab}$ & $2.21 \mathrm{a}$ & $2.24 \mathrm{a}$ \\
No fertilizer & $0.98 \mathrm{~d}$ & $0.88 \mathrm{~d}$ & $0.97 \mathrm{c}$ & $0.82 \mathrm{c}$ \\
\hline
\end{tabular}

Values followed by same letter(s) in the same column are not significantly different at $\mathrm{P} \leq 0.05$

Table 3. Cassava root yield $\left(\mathrm{t} \mathrm{ha}^{-1}\right)$ as affected by different Organic - Based Fertilizer (OBF) rates and combination with NPK in Ibadan and Ilora

\begin{tabular}{lcccc}
\hline & \multicolumn{2}{c}{ Ibadan } & \multicolumn{2}{c}{ Ilora } \\
\hline Treatments & 2006 & 2007 & 2006 & 2007 \\
$2.5 \mathrm{t} \mathrm{ha}^{-1} \mathrm{OBF}$ & $9.81 \mathrm{c}$ & $10.75 \mathrm{c}$ & $9.49 \mathrm{c}$ & $9.99 \mathrm{c}$ \\
$5.0 \mathrm{t} \mathrm{ha}^{-1} \mathrm{OBF}$ & $12.10 \mathrm{~b}$ & $12.80 \mathrm{~b}$ & $10.52 \mathrm{~b}$ & $11.12 \mathrm{bc}$ \\
$10 \mathrm{t} \mathrm{ha}^{-1} \mathrm{OBF}$ & $14.34 \mathrm{a}$ & $14.76 \mathrm{a}$ & $12.31 \mathrm{a}$ & $12.72 \mathrm{a}$ \\
$2.5 \mathrm{t} \mathrm{ha}^{-1} \mathrm{OBF}+100 \mathrm{~kg} \mathrm{ha}^{-1} \mathrm{NPK}$ & $10.64 \mathrm{c}$ & $11.42 \mathrm{c}$ & $10.02 \mathrm{~b}$ & $10.78 \mathrm{c}$ \\
$5.0 \mathrm{t} \mathrm{ha}^{-1} \mathrm{OBF}+100 \mathrm{~kg} \mathrm{ha}^{-1} \mathrm{NPK}$ & $13.17 \mathrm{a}$ & $13.90 \mathrm{ab}$ & $11.75 \mathrm{a}$ & $11.97 \mathrm{ab}$ \\
$400 \mathrm{~kg} \mathrm{ha}^{-1} \mathrm{NPK}$ & $10.03 \mathrm{c}$ & $10.99 \mathrm{c}$ & $10.04 \mathrm{bc}$ & $9.74 \mathrm{c}$ \\
No fertilizer & $7.59 \mathrm{~d}$ & $7.11 \mathrm{~d}$ & $6.94 \mathrm{~d}$ & $6.41 \mathrm{~d}$ \\
\hline
\end{tabular}

Values followed by same letter(s) in the same column are not significantly different at $\mathrm{P} \leq 0.05$

Table 4. Changes in soil N, P, K and Organic C contents with different Organic - Based Fertilizer (OBF) rates and combination with NPK after cropping for two years

\begin{tabular}{|c|c|c|c|c|c|c|c|c|}
\hline & $\begin{array}{c}\mathrm{N} \\
\left(\mathrm{g} \mathrm{kg}^{-1}\right)\end{array}$ & $\begin{array}{c}\mathrm{P} \\
\left(\mathrm{mg} \mathrm{kg}^{-1}\right)\end{array}$ & $\begin{array}{c}\mathrm{K} \\
\left.(\mathrm{cmol} \mathrm{kg})^{-1}\right)\end{array}$ & $\begin{array}{c}\text { Org C } \\
\left(\mathrm{g} \mathrm{kg}^{-1}\right)\end{array}$ & $\begin{array}{c}\mathrm{N} \\
\left(\mathrm{g} \mathrm{kg}^{-1}\right)\end{array}$ & $\begin{array}{c}\mathrm{P} \\
\left(\mathrm{mg} \mathrm{kg}^{-1}\right)\end{array}$ & $\begin{array}{c}\mathrm{K} \\
\left(\mathrm{cmol} \mathrm{kg}^{-1}\right)\end{array}$ & $\begin{array}{l}\text { Org C } \\
\left(\mathrm{g} \mathrm{kg}^{-1}\right)\end{array}$ \\
\hline & \multicolumn{4}{|c|}{ Ibadan } & \multicolumn{4}{|c|}{ Ilora } \\
\hline Pre cropping & 1.20 & 1.60 & 0.28 & 10.20 & 0.89 & 3.60 & 0.24 & 7.10 \\
\hline $2.5 \mathrm{tha}^{-1} \mathrm{OBF}$ & $1.29 \mathrm{~d}$ & $1.90 \mathrm{c}$ & $0.24 \mathrm{c}$ & $10.22 \mathrm{c}$ & $1.01 \mathrm{c}$ & $3.53 \mathrm{~cd}$ & $0.21 \mathrm{c}$ & $7.15 \mathrm{c}$ \\
\hline $5 \mathrm{tha}^{-1} \mathrm{OBF}$ & $1.36 \mathrm{c}$ & $2.00 \mathrm{c}$ & $0.29 \mathrm{~b}$ & $10.55 b c$ & $1.18 \mathrm{~b}$ & $3.81 \mathrm{bc}$ & $0.25 b c$ & $7.50 \mathrm{bc}$ \\
\hline $10 \mathrm{tha}^{-1} \mathrm{OBF}$ & $1.50 \mathrm{a}$ & $2.65 \mathrm{a}$ & $0.34 \mathrm{a}$ & $12.83 \mathrm{a}$ & $1.26 \mathrm{a}$ & $4.45 \mathrm{a}$ & $0.30 \mathrm{a}$ & $8.55 \mathrm{a}$ \\
\hline $\begin{array}{l}2.5 \mathrm{t} \mathrm{ha}^{-1} \mathrm{OBF} \\
+100 \mathrm{~kg} \mathrm{ha}^{-1} \mathrm{NPK}\end{array}$ & $1.38 \mathrm{c}$ & $2.13 b c$ & $0.28 \mathrm{~b}$ & $10.85 b$ & $1.07 \mathrm{~b}$ & $3.67 \mathrm{c}$ & $0.23 \mathrm{c}$ & $7.31 \mathrm{c}$ \\
\hline $\begin{array}{l}5.0 \mathrm{t} \mathrm{ha}^{-1} \mathrm{OBF} \\
+100 \mathrm{~kg} \mathrm{ha}^{-1} \mathrm{NPK}\end{array}$ & $1.47 \mathrm{~b}$ & $2.29 b$ & $0.30 \mathrm{~b}$ & $11.01 \mathrm{~b}$ & $1.22 \mathrm{ab}$ & $4.04 \mathrm{~b}$ & $0.26 \mathrm{~b}$ & $7.73 b$ \\
\hline $400 \mathrm{~kg} \mathrm{ha}^{-1} \mathrm{NPK}$ & $1.04 \mathrm{e}$ & $1.66 \mathrm{~d}$ & $0.24 \mathrm{c}$ & $8.25 \mathrm{~d}$ & $0.84 \mathrm{c}$ & $3.48 \mathrm{~cd}$ & $0.20 \mathrm{c}$ & $6.13 \mathrm{~d}$ \\
\hline No fertilizer & $0.90 \mathrm{f}$ & $1.51 \mathrm{~d}$ & 0.18 & 8.10 & $0.64 \mathrm{~d}$ & $3.34 \mathrm{~d}$ & $0.15 \mathrm{~d}$ & $5.66 \mathrm{e}$ \\
\hline
\end{tabular}

Values followed by same letter(s) in the same column are not significantly different at $\mathrm{P} \leq 0.05$ 